DOI No: http://dx.doi.org/10.29228/Joh.48942

Authenticity process is conducted by

Makale Türü: Araştırma makalesi

Geliş Tarihi: 18-01-2021

Kabul Tarihi: 16-04-2021

On-line Yayın: 30-04-2021

Article Type: Research article Submitted: 18-01-2021

Accepted: 16-04-2021

Published Online: 30-04-2021

Atıf Bilgisi / Reference Information

Kan, A. Ü. \& Özmen, E. (2021). Metaphoric Perceptions of Pre-Service Teacher on Distance Education During the Covid-19 Pandemic. Journal of History School, 51, 1085-1118.

\title{
METAPHORIC PERCEPTIONS OF PRE-SERVICE TEACHER ON DISTANCE EDUCATION DURING THE COVID-19 PANDEMIC ${ }^{1}$
}

\section{Ayșe Ülkü KAN ${ }^{2}$ \& Erhan ÖZMEN ${ }^{3}$}

\begin{abstract}
With the emergence of the coronavirus (Covid-19) pandemic, distance education applications (emergency) have been activated in all educational institutions. This situation has also affected higher education closely. This study aimed to reveal the perceptions of pre-service teachers towards distance education applied during the Covid19 pandemic through metaphors. The research was conducted in a phenomenological design. The study group of the study was determined in accordance with convenience sampling and consisted of 402 teacher candidates who continue their education at a university. Data was collected with forms containing the sentence: "Pandemic period distance education is like ...... ; because.......". The data were analyzed by content analysis. Participants developed 178 metaphors. These metaphors are grouped into six positive and four negative categories. Considering the metaphors used, distance education was mostly explained with the metaphors of medicine, heroes, water, food, vitamins, and

\footnotetext{
${ }^{1}$ Article writing author influence rate: 1 st author: $50 \%$, 2nd author: $50 \%$. Ethics committee approval for this article was obtained at Frat University with the number 97132852/100/ -11 and meeting number.

${ }^{2}$ Assoc. Prof., Firat University, Faculty of Education, Department of Educational Sciences, Department of Education Programs and Instruction, aulkukan@yahoo.com, Orcid: 0000-00021524-3326

${ }^{3}$ Instructor, Firat University Distance Education Center,eozmen@ firat.edu.tr, Orcid: 0000-00024013-6004
} 


\section{Ayșe Ülkü KAN \& Erhan ÖZMEN}

it was emphasized that distance education was necessary and supportive. In addition, it was underlined that there are deficiencies regarding the process and that it should be more efficient.

Keywords: Distance Learning, Emergency Remote Teaching, Covid-19, Pandemic, Metaphor

\section{Öğretmen Adaylarının Covid-19 Pandemisi Dönemindeki Uzaktan Eğitime Yönelik Metaforik Algıları}

\section{$\ddot{O} z$}

Koronavirüs (Covid-19) pandemisinin ortaya çıkması ile birlikte tüm eğitim kurumlarında (acil) uzaktan eğitim uygulamaları etkin hale getirilmiştir. $\mathrm{Bu}$ durum yüksek öğretimi de yakından etkilemiştir. Bu araştırma, öğretmen adaylarının Covid-19 pandemisi döneminde uygulanan uzaktan eğitime yönelik algılarını metaforlar aracılığıyla ortaya koymayı amaçlamıştır. Araştırma olgubilim deseninde yürütülmüştür. Araştırmanın çalışma grubu kolay ulaşılabilir durum örneklemesine uygun olarak belirlenmiştir ve bir üniversitede öğrenimine devam eden, 402 öğretmen adayından oluşturulmuştur. Araştırma verileri, "Pandemi dönemi uzaktan eğitim....... gibidir/benzer; Çünkü......." cümlesinin yer aldığı formlarla toplanmıştır. Veriler içerik analizi ile çözümlenmiştir. Katılımcılar 178 metafor geliştirmiştir. Bu metaforlar, altı olumlu dört olumsuz kategoride toplanmıştır. Kullanılan metaforlar dikkate alındığında pandemi dönemi uzaktan eğitim en çok ilaç, kahraman, su, yemek, vitamin metaforlarıyla açıklanırken uzaktan eğitimin gerekli ve destekleyici olduğu vurgulanmıştır. Bunun yanında sürece ilişkin eksiklerinin olduğu ve daha verimli olması gerektiğinin altı çizilmiştir.

Keywords: Uzaktan Eğitim, Acil Uzaktan Öğretim, Covid-19, Pandemi, Metafor

\section{INTRODUCTION}

The increasing expansion and normalization of information technologies in the 2000s heralded a new world to humanity. The rapid global spread of a virus that allegedly emerged in China at the end of 2019, forced people to a different lifestyle and immensely accelerated the expansion of information technologies. The speed of this expansion significantly impacted education, which was a natural part of life. Social isolation, i.e. staying at home, became necessary to prevent the spread of the virus. After the healthcare industry, education was the industry that suffered the largest impact of this situation (Telli and Altun, 2020). According to Zhong (2020), United Nations data indicate that 770 million students were directly affected by this situation. Experts' prediction that the pandemic will take a while to reach its end (Liu, Gayle, Wilder-Smith and 
Metaphoric Perceptions of Pre-Service Teacher on Distance Education During...

Rocklöv, 2020) and the decreasing functionality of education institutions, brought the debate on distance education, with its controversial impact on education, once more into the limelight. The virus continued its rapid spread throughout the world and was first identified in Turkey on March 11, 2020 (Ministry of Health, 2020). Consequently, government organizations took some measures to resist the pandemic. In this regard, Higher Education Board (YÖK) ruled that as of March 23, 2020, universities with appropriate infrastructure in place can continue education distancely and most universities transitioned to distance education (YÖK, 2020).

Many governments considered distance education the most practical solution for the continuity of education during the pandemic. The fact that many distance education platforms that have agreements with major universities are being widely used throughout the world made this transition easier (Telli and Altun, 2020). Considering digital transformation in light of previous studies, under normal circumstances, this transition should have taken approximately 108 years, but it happened in about one month during the pandemic, even though the level of transition varied depending on organizations' digital infrastructures (Öz, Celayir and Onursal, 2020).

Distance education is an educational technology application in which the learner and the teacher are located in different locations, that allow independent, individual and flexible learning, and that uses technological tools for interaction and communication (Uşun, 2006). Compared to conventional education, distance education has certain advantages. Its affordability and accessibility are two of these (Traxler, 2018). In addition, its ability to provide an effective learning environment through multimedia tool, to reach a significant number of students, to allow students to direct their own education based on their individual speeds and to transcend time-space for education are also its other advantages over conventional education (Arat and Bakan, 2014). In addition to its advantages, distance education also has some disadvantages. The preparation necessary to begin distance education may be considered such a disadvantage. Education organizations have to achieve certain quality standards in order to use distance education as a supporting or alternative education practice. Many scholars carried out various studies on this issue in order to meet quality standards in distance education (Kaban, 2013). In order to meet quality standards, the process has to be fully planned from start to finish and be executed online. During the global pandemic, this is not a realistic approach. In crises, education organizations have to resort to different solutions than online, well-planned distance education applications. Emergency Remote Teaching is one of these solutions. Emergency remote teaching is a distance education activity used to produce temporary 
solutions to current needs when distance education is mandatory (Ulus, 2020). In contrast with experiences that are planned in advance and designed to be online, emergency remote teaching is a temporary alternative modality of education due to crises. Under these circumstances, the primary goal is not to recreate a solid education ecosystem, but to allow temporary access to education and teaching supports in a manner that can be rapidly set up and reliably used in an emergency or crisis (Hodges, Moore, Lockee, Trust and Bond, 2020). Considering this definition, emergency remote teaching is an educational application that is different than distance education in various aspects, and that is temporarily used instead of in-person education in line with available technological means during crises. Education technologies scholars suggested the name "emergency remote teaching" in order to differentiate this application from distance education in normal times (Hodges et al., 2020). Emergency remote teaching applications may be deficient and inadequate in many aspects because they are established in a short period of time. Because of this, emergency remote teaching, which is different than distance education (Shisley, 2020) becomes more difficult to comprehend perceptually. Effective use of distance education in the living conditions dubbed the new normal during and after the pandemic is closely related to students' perceptions of distance education. There are diverse means of revealing these perceptions in students. One of these involve metaphors. Metaphors are constructs that are used to strengthen the narrative to express a concept, to enrich the language, to use different concepts and express mentally constructed meanings into words (Yalçın and Erginer, 2012).

Metaphors are defined as concepts that naturally have multiple meanings and that can shed light on our mental world. In essence, metaphor means perceiving/experiencing something by considering something else (Lakoff and Johnson, 2005), and its etymology reveals Ancient Greek words "metapherein" and "metaphero" (Cebeci, 2013). This ancient word means "to carry" and "to transfer" and is a compound word consisting of the words "meta" and "pherin". Metaphors are easily understandable because they induce semantic connotation (Ocak and Gündüz, 2006). Metaphors reveal how we interpret our daily routines, and also shape our thoughts and actions (Kılıç and Arakan, 2010). While metaphors make discovering a piece of knowledge easier, they are also a way to think and see (Morgan, 1998). It is expected that this aspect of metaphors will make prospective teachers understand emergency remote teaching more clearly. It is important for prospective teachers to understand emergency remote training better in order for this concept to develop further. In this regard, we think that the results of the analysis of metaphors that emerged from prospective teachers' opinions may contribute to the literature. In this context, the purpose of this study 
Metaphoric Perceptions of Pre-Service Teacher on Distance Education During...

is to reveal the perceptions of pre-service teachers towards distance education applied during the covid-19 pandemic through metaphors. For this purpose, answers to the following questions were sought in the study:

1. What are the metaphors pre-service teachers created regarding distance education during the pandemic?

2. In which conceptual categories can the metaphors created by pre-service teachers be collected?

\section{METHOD}

Qualitative research is one of the means of generating knowledge that humans established in order to reveal the secrets of its identity, and to discover the depths of social systems that it shaped through its own efforts (Özdemir, 2010). Studies that use the qualitative method aim to achieve a deep understanding about the subject matter of the study. In this regard, the researcher acts like an explorer, tries to achieve the truth through additional questions, and values the opinions of people who participate in the study (Karataş, 2015). In this study, phenomenology, which is a qualitative study method was used. Phenomenology is a qualitative study method that investigates in detail the facts that we encounter but don't have in-depth information about, or didn't think about (Yıldırım and Şimşek, 2016). Phenomenology studies investigate groups in terms of their feelings about their experiences, the concepts they create in their minds and their opinions. It examines the state of consciousness that consequently emerges (Patton, 2002). In studies in accordance with the phenomenological pattern, data analysis is carried out through content analysis that can reveal meanings. The aim is to reach themes that can express the phenomenon (Yildirım and Şimşek, 2016). In this study, perceptions of prospective teachers concerning the distance education practice during the pandemic were determined through metaphors and interpreted.

\section{Study group}

"Convenience sampling" was used as sampling method in this study. This method allows the authors to select a condition that is nearby and accessible (Yıldırım and Şimşek, 2016). The study group consists of 402 volunteer students attending the 2019-2020 spring term education through the distance education platform at the Faculty of Education of a university located in the Eastern Anatolia Region. 96 of 402 students were male, 306 were female. Table 1 presents demographic information about participating prospective teachers. 


\section{Ayşe Ülkü KAN \& Erhan ÖZMEN}

\section{Table 1}

Demographic Information about Participating Prospective Teachers

\begin{tabular}{llccc}
\hline Variable & Subvariable & f & \% & Total \\
\hline Gender & Female & 306 & 76,1 & \multirow{2}{*}{402} \\
& Male & 96 & 23,8 & \\
& Sciences Teaching & 10 & 2,4 & \\
& Primary School Mathematics Teaching & 16 & 3,9 & \\
& English Language Teaching & 19 & 4,7 & \\
& Pre-school Teaching & 86 & 21,3 & \\
& Psychological Consultancy and Guidance & 50 & 12,4 & \multirow{2}{*}{402} \\
& Painting Teaching & 32 & 7,9 & \\
& Classroom Teaching & 78 & 19,4 & \\
& Social Sciences Teaching & 68 & 16,9 & \\
Had distance & Turkish Language Teaching & 43 & 10,6 & \\
learning experience & Yes & 174 & 43,2 & \multirow{2}{*}{402} \\
Class Level & No & 228 & 56,7 & \\
& Freshmen & 74 & 18,4 & \\
& Sophomores & 104 & 25,8 & \multirow{2}{*}{402} \\
& Juniors & 79 & 19,6 & \\
\hline
\end{tabular}

Table 1 contains demographic information about participats. According to the table $76.1 \%$ of the study group consists of female and $23.8 \%$ consists of male. Participants' were enrolled in 9 different departments, Sciences Teaching 2.4\%, Primary School Mathematics Teaching 3.9\%, English Language Teaching 4.7\%, Pre-school teaching 21.3\%, Psychological consultancy and guidance 12.4\%, Painting teaching $7.9 \%$, Classroom teaching $19.4 \%$, Social sciences teaching $16.9 \%$, Turkish Language Teaching $10.6 \% .18 .4 \%$ of participants were freshmen, $25.8 \%$ were sophomores, $19.6 \%$ were juniors and $36 \%$ were seniors. $43.2 \%$ of the study group had distance learning experience while $56.7 \%$ didn't.

\section{Data collection}

This study uses an interview form developed by the authors for data collection. This form asks the participant to fill in the blanks in the statement "Distance education is like .............. Because...................". The term "because" was included to guide participating prospective teachers to offer a logical basis for their metaphors. Furthermore, the question forms include a personal information area in which participants can specify their departments, genders, seniority and previous distance education experience. For data collection, the forms were delivered to volunteering participants through the distance education platform, considering the pandemic conditions, and were recollected through the same platform. 
Metaphoric Perceptions of Pre-Service Teacher on Distance Education During...

\section{Data analysis}

Answers of prospective teachers were examined and checked for compatibility with the study's purpose before being analyzed. Forms of participants who didn't use a metaphor, or could not justify the metaphor were excluded. In this context, 24 of 426 forms were excluded from analysis.

This study uses content analysis, a data analysis method frequently used in social sciences. Content analysis is a method that differentiates, compares, systematizes the data through an in-depth process and to interpret the results in a comprehensible manner (Y1ldırım and Şimşek, 2016). Content analysis combines similar statements in textual data through certain classification processes to interpret them in a comprehensible and meaningful way. The fundamental logic of this analysis method is to consider common aspects of similar data for categorization, and to interpret them by assigning quantitative meanings to qualitative data (Gökçe, 2006).

In this study, various steps have been followed while analyzing the data. The phases were established based on data from the literature (Saban and Koçbeker, 2006).

1. Meaning assignment: At this stage, students' answers were examined and it was noted whether the developed metaphors were meaningful or not. Students' metaphors (prison, medicine, hero, bicycle, etc.) were conceptually defined.

2. Elimination: At this stage, the forms filled in by the students were examined once again. 24 forms that did not contain a metaphor suitable for the purpose of the study or were thought to be incompatible with the justification of the metaphor were eliminated. 402 forms were included in the analysis.

3. Categorization: The metaphors that students created for distance education during the pandemic period were discussed with the reasons they emphasized, and the metaphors were categorized according to their similar aspects.

4. Validity and reliability: Analyzes were made by two researchers. Metaphors and created categories were compared in order to verify the power of representation. In addition, it was taken into consideration in cases where a consensus was reached using Miles and Huberman's (1994) formula and where no consensus was reached. The reliability level was determined as .91 .

5. Metaphor-based interpretation: The metaphors were categorized and presented in tables. The frequency values of each metaphor are given in the tables. 


\section{Ayșe Ülkü KAN \& Erhan ÖZMEN}

Sample sentences describing the metaphors and their reasons are presented in the findings section together with the participant number. A word cloud was created considering the frequency of the metaphors used in the categories. The "Wordart" website (www.wordart.com) was used to create the word cloud.

\section{FINDINGS AND INTERPRETATION}

This section contains the findings that emerged after the analysis of the study data. While interpreting the tables, direct quotations were given from the opinions of the participants. Student forms are numbered between 1 and 402. The letter $\mathrm{F}$ was used when giving opinions of female participants, and $\mathrm{M}$ was used when giving opinions of male participants. The metaphors revealed were classified under 10 categories (six positive, four negative). Positive categories

were Individuality, Continuity, Diversity, Guidance, Affordability and Accessibility, Necessary and Supportive; negative categories were Complexity and Uncertainty, Inadequacy and Inefficiency, Non-interactivity and Difficulty.

\section{Findings for positive metaphors}

This section presents the positive metaphors suggested for distance education during the pandemic by prospective teachers.

\section{Findings for the individuality category and relevant metaphors}

Metaphors for the "Individuality" category are presented in Table 2.

Table 2 indicates that there are 13 metaphors concerning the individuality category. These metaphors are, in order of frequency, reading a book, gear shift, swimming, control, canoe, bicycle, rope jumping, tree climbing, chick hatching from an egg, flower care, study room, ploughing a field and pandemic. The most frequent metaphor used by prospective teachers in this category was "reading $a$ book". A prospective teacher (312.F) explained the book reading metaphor: "...because as long as you hold it in your hands, you're in that world". Another prospective teacher who used the "gear shift" metaphor (17.F) justified it with the words "...because you can control the speed when you want to". A prospective teacher who used the metaphor "swimming" in the individualism category (361.M) said "because you can move forward when you stroke" to emphasize individual efforts. Another prospective teacher who used the metaphor "control" (369.F) emphasized the controllability of distance education with the words "..because you can guide the process any way you want". Another student who wanted to emphasize individual effort (129.F) used the metaphor "bicycle" and said "...because you fall if you don't pedal". 
Metaphoric Perceptions of Pre-Service Teacher on Distance Education During...

Table 2

Metaphors for the Individuality Category

\begin{tabular}{lllll}
\hline No. & Metaphor & f & Resemblance aspect & Category \\
\hline 1 & Reading a book & 5 & Require individual effort & \\
2 & Gear shift & 3 & Controllability & \\
3 & Swimming & 3 & Require individual effort & \\
4 & Control & 3 & Controllability & \\
5 & Cano & 2 & Require individual effort & \\
6 & Bicycle & 2 & Require individual effort & Metaphors for the \\
7 & Rope jumping & 2 & Require individual effort & Individuality \\
8 & Tree climbing & 1 & Require individual effort & Category \\
9 & Chick hatching from an egg & 1 & Require individual effort & \\
10 & Flower care & 1 & Require individual effort & \\
11 & Study room & 1 & To belong to the person & \\
12 & Ploughing a field & 1 & Require individual effort & \\
13 & Pandemic & 1 & The imperative of & \\
& & & individual control & \\
\hline
\end{tabular}

A student emphasizing the individual nature of distance education during the pandemic (192.F) used the metaphor "study room" and explained this metaphor with the words "because everything inside it belong to you". A prospective teacher used the metaphor "epidemic" for distance education during the pandemic (90.M) "...because once you lose its control, you can't regain it". The word cloud for the individuality category is presented in Figure 1.

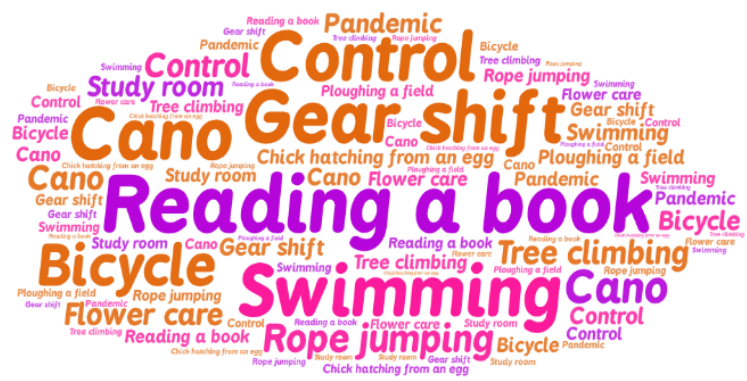

Figure 1. Word cloud for the individualism category.

\section{Findings for the Continuity Category and relevant Metaphors}

Metaphors for the "Continuity" category are presented in Table 3.

Table 3 indicates that there are 3 metaphors concerning the continuity category. These metaphors are, in order of frequency, refrigerator, powerbank and lifelong 
learning. In the continuity category, the most common metaphors used by prospective teachers were refrigerator and powerbank.

\section{Table 3}

Metaphors for the Continuity Category

\begin{tabular}{llllc}
\hline No. & Metaphor & f & Resemblance aspect & Category \\
\hline 1 & Refrigerator & 2 & Providing continuity & Metaphors for the \\
2 & Powerbank & 2 & Providing continuity & Continuity Category \\
3 & Lifelong learning & 1 & To be continuous & \\
\hline
\end{tabular}

One of the prospective teachers (401.F) used "refrigerator" as a metaphor for distance education and justified it by saying "because just like the refrigerator keeps food fresh, distance education keeps knowledge fresh, doesn't allow it to go stal". Another prospective teacher (402.M) used the metaphor "powerbank" and explained that "...because it allows continued access". A prospective teacher (330.F) used "lifelong learning" as a metaphor, justifying it with the statement "...because in this process, it taught us that learning never ends, it continues from birth to death" emphasizing continuity. The word cloud for the continuity category is presented in Figure 2.

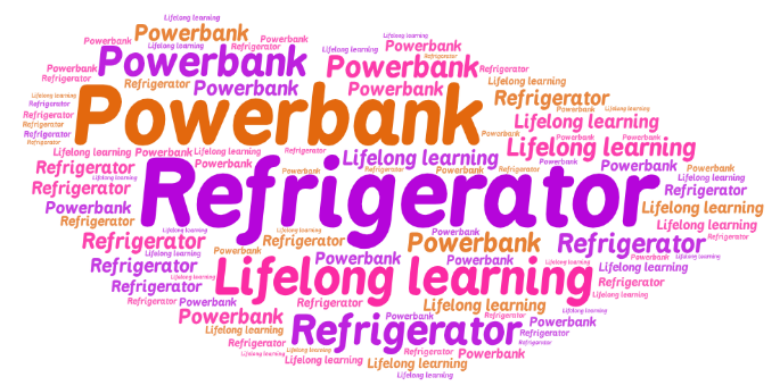

Figure 2. Word cloud for the continuity category.

\section{Findings for the Diversity Category and relevant Metaphors}

Metaphors for the "Diversity" category are presented in Table 4 . Table 4 indicates that there are 15 metaphors concerning the diversity category. These metaphors were, in order of frequency, rainbow, google, book, soup, sea, ashura, exhibition, YouTube, capsule, world, internet, marketplace, social media, and Istanbul. The most frequent metaphor used by prospective teachers in the diversity category was "rainbow". One prospective teacher (46.F) used the metaphor "rainbow" and justified it with "...because it contains the colors I like 
Metaphoric Perceptions of Pre-Service Teacher on Distance Education During...

and don't like". Another prospective teacher (174.F) used "google" as a metaphor "...because we can access information anytime we like".

\section{Table 4}

Metaphors for the Diversity Category

\begin{tabular}{lllll}
\hline No. & Metaphor & f & Resemblance aspect & Category \\
\hline 1 & Rainbow & 5 & Color diversity & \\
2 & Google & 4 & Information diversity & \\
3 & Book & 4 & Information diversity & \\
5 & Soup & 4 & Content diversity & \\
6 & Sea & 3 & Living diversity & \\
7 & Ashura & 2 & Content diversity & \\
8 & Exhibition & 2 & Product diversity & Metaphors for the Diversity \\
9 & Youtube & 2 & Information diversity & Category \\
10 & Capsule & 2 & Information diversity & \\
11 & World & 1 & Information diversity & \\
12 & Internet & 1 & Information diversity & \\
13 & Marketplace & 1 & Product diversity & \\
14 & Social Media & 1 & Information diversity & \\
15 & Istanbul & 1 & Human diversity & \\
\hline
\end{tabular}

Another prospective teacher who emphasized diversity of information (313.F) used the metaphor "book", "...because books are pools of knowledge, you can access any knowledge you like". A prospective teacher used "soup" as a metaphor for distance education in terms of content diversity (397.F) "...because it contains many nutrients you need". Another used "sea" as a metaphor (395.F) "...because it contains much more value and responsibility than what you can see above the water". Another prospective teacher (31.M) used "ashura" as a metaphor for the content diversity of distance education, "...because you can find any vitamin you look for". Another prospective teacher (176.M) used "exhibition" as a metaphor "... because all the products you look for are there". Another metaphor in the diversity category is "capsule". A prospective teacher who used it (23.F) said "...because it transfers large amounts of information through the shortest path". Another prospective teacher (32.F) used the metaphor "Istanbul" and likened distance education during the pandemic to Istanbul, in which diverse people live. A prospective teacher said "...because you can encounter many people from every culture, every language". The word cloud for the diversity category is presented in Figure 3. 


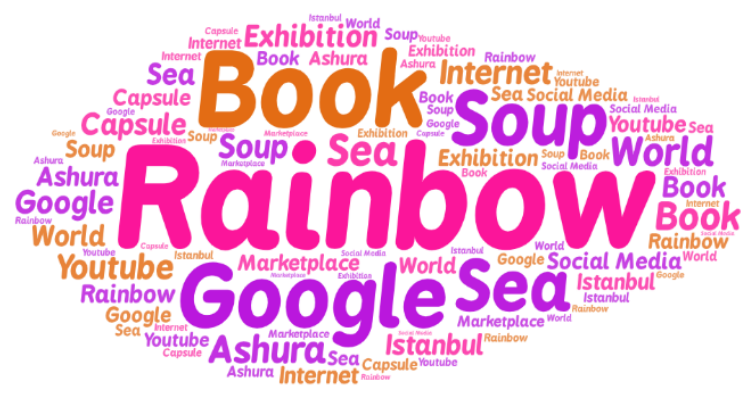

Figure 3. Word cloud for the diversity category.

\section{Findings for the Guidance Category and relevant Metaphors}

Another category that emerged for distance education during the pandemic was "Guidance". This category and the metaphors are presented in Table 5.

\section{Table 5}

Metaphors for the Guidance Category

\begin{tabular}{llllc}
\hline No. & Metaphor & f & Resemblance aspect & Category \\
\hline 1 & Technical coach & 3 & Guide & Metaphors for the Guidance \\
2 & Flashlight & 3 & Lighting the way & Category \\
3 & Compass & 3 & Guide & \\
4 & North Star & 2 & Guide & \\
5 & Guide & 2 & Guide & \\
6 & Mirror & 1 & Providing self-control & \\
\hline
\end{tabular}

Table 5 indicates that there are six metaphors concerning the guidance category. These metaphors are, in order of frequency, technical coach, flashlight, compass, north star, guide and mirror. Prospective teachers most commonly likened distance education during the pandemic to technical coach, flashlight and compass, which were used with the same frequency. A student who used the metaphor "technical coach" (98.M) said it was "...because even distancely attending the lectures that are filled with optimistic positive energy improves our morale and motivation, allows us to think positively". One of the most common metaphors in the guidance category was flashlight. A student who used "flashlight" as a metaphor for distance education during the pandemic (112.F) said "...because it sheds light on our path and illuminates our lives". Another student (163.F) used "compass" another common metaphor, and said "...because it allowed us to find our path in our education life in this period". Another metaphor in this category is "north star". A prospective teacher (392.F) used this metaphor and said "...because it defined the orientation of our education life". Another prospective teacher likened distance education during the pandemic to a 
Metaphoric Perceptions of Pre-Service Teacher on Distance Education During...

"guide" (110.F) "...because it tells you where to go and how". The last metaphor in this category is "mirror". A prospective teacher likened distance education during the pandemic (239.M) to a mirror, "...because it allows us to see our shortcomings in our classes or things that we couldn't learn". The word cloud for the guidance category is presented in Figure 4.

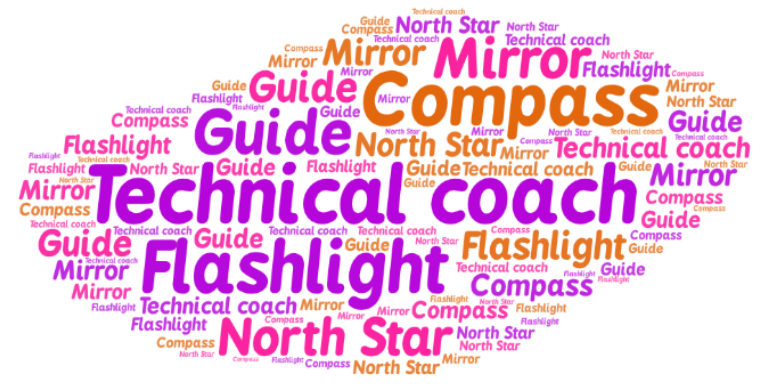

Figure 4. Word cloud for the guidance category.

\section{Findings for the affordability and accessibility category and relevant metaphors}

Metaphors for the "Affordability and Accessibility" category are presented in Table 6. Table 6 indicates that there are 18 metaphors concerning the diversity category. These metaphors are, in order of frequency, friend, mother, magic lamp, google, street lamp, jet, airplane, bridge, neighbor, school at home, teaser trailer, social media, star in the sky, time travel, magic carpet, lottery, and discount. A prospective teacher used the metaphor "friend" which was the most common word (128.F), "...because it accompanied us in these difficult times to avoid disrupting our education". Another common metaphor was "mother" and a prospective teacher who used it (99.F) said it was "...because it is with you in your bad times". Another prospective teacher who emphasized time flexibility (97.F) used the metaphor "magic lamp", "...because you can learn whenever you want regardless of time and space". Another prospective teacher likened distance education during the pandemic to "Google" (100.F) "...because you can immediately find the information you seek". A prospective teacher likened distance education during the pandemic to a "street lamp". (182.F) "...because it illuminates everyone without having to pay money". Another prospective teacher used the metaphor "Jet". (350.F) "...because it is very efficient in using time". One prospective teacher used "bridge" as a metaphor. (344.F) "...because we can learn from teachers who are miles away in this period of advanced technology". 
A prospective teacher mentioned the accessibility aspect of distance education during the pandemic (231.F) used the metaphor "neighbor", "...because it is easily available anytime, whenever you like". Another prospective teacher (367.F) likened it to "time travel" and said "...because you can see the lectures from anytime you like". One prospective teacher likened distance education during the pandemic to "lottery", (74.F) because "...you can enrich your knowledge base in a very short time". Another prospective teacher (322.F) used the metaphor "discount", "...because you can reach any product with less money and effort". The word cloud for the affordability and accessibility category is presented in Figure 5.

\section{Table 6}

Metaphors for the Affordability and Accessibility Category

\begin{tabular}{llllc}
\hline No. & Metaphor & f & Resemblance aspect & Category \\
\hline 1 & Friend & 5 & Always with you & \\
2 & Mother & 4 & Always with you & \\
3 & Magic lamp & 3 & Time flexibility & \\
5 & Google & 3 & Accessing opportunities & \\
6 & Street lamp & 2 & Lighting everyone & \\
7 & Jet & 2 & Being fast & Metaphors for the \\
8 & Airplane & 2 & Being fast & Affordability and \\
9 & Bridge & 2 & Being unifying & Accessibility \\
10 & Neighbor & 2 & To be close & Category \\
11 & School at Home & 1 & Saving time and space & \\
12 & Teaser trailer & 1 & Getting information fast & \\
13 & Social media & 1 & Accessing opportunities & \\
14 & Star in the sky & 1 & Lighting everyone & \\
15 & Time travel & 1 & Time flexibility & \\
16 & Magic carpet & 1 & Being fast & \\
17 & Lottery & 1 & A lot of gain with little effort & \\
18 & Discount & 1 & Less cost & \\
\hline
\end{tabular}

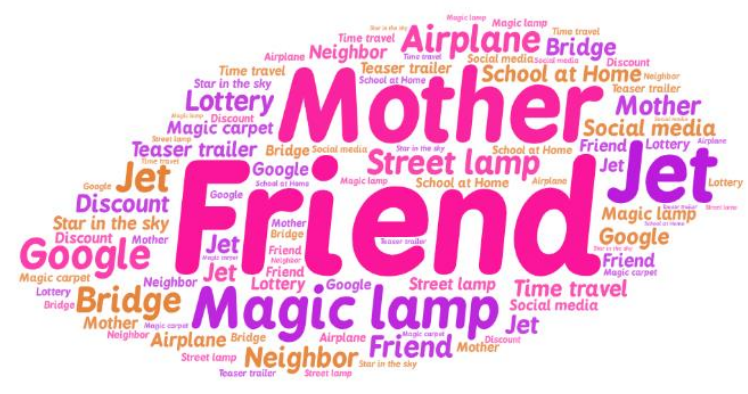

Figure 5. Word cloud for the affordability and accessibility category. 
Metaphoric Perceptions of Pre-Service Teacher on Distance Education During...

\section{Findings for the necessary and supportive category and relevant metaphors}

Another category that emerged for distance education during the pandemic was "being necessary and supportive" This category and the metaphors it includes are presented in Table 7.

Table 7 indicates that there are 33 metaphors concerning the diversity category. These metaphors are, in order of frequency, medicine, hero, water, crutch, food, vitamin, band-aid, mask, respirator, spare tire, first-aid kit, doctor, cane, lifeguard, safety belt, hospital, boat, patch, breath, first-aid, life raft, winter coat, prosthetics, sap water, draft paper, fire extinguisher, intensive care, desert plant, antidote, IV bag, compensation training, antibiotics, and sunglasses. The most common metaphor in the being necessary and supportive category was "medicine", which was also the most frequently used metaphor in all categories. Distance education during the pandemic was most frequently likened to a medicine by prospective teachers, and this metaphor was justified through various explanations. A prospective teacher using the medicine metaphor (19.F) said "...because this disease has no known cure. This is why distance education acts as a medicine by allowing social distancing". Another prospective teacher who used the "medicine" metaphor (39.M) said it was "...because it allowed continuity of education despite the virus". Another metaphor that was very frequently used in this and other categories was "hero". A prospective teacher who used this metaphor (8.F) said it was "...because it accompanied us in the most difficult times". Another prospective teacher who used the same metaphor (301.F) said it was "...because it allowed students a safe education in their homes, away from the viral threat". Another very common metaphor was "water".

A prospective teacher who used this metaphor (13.F) said it was "...because education is vital and distance education in the pandemic gave back our right to education, which was lost in this period". A prospective teacher who wants to emphasize the supportive role of distance education during the pandemic (89.M) used the metaphor "crutch", "...because it allowed us to keep walking in our education life". Another prospective teacher (45.F) used "mask" a frequently used item during the pandemic, as a metaphor "...because just like masks allow us to take measures to protect ourselves from the disease, distance education also takes the necessary measures and protects us from the epidemic". A prospective teacher (332.M) likened distance education during the pandemic to a "spare tire" "...because it's like a not-so-healthy period that we try to get through". Another prospective teacher (68.F) used the metaphor "lifeguard", "...because it accompanied us in the most difficult times in our education life". Another 
prospective teacher (331.M) used the metaphor "patch", "...because it covered many of our shortcomings during the pandemic". A prospective teacher (196.F) likened distance education during the pandemic to a "drafting paper", "...because distance education provides a one-time benefit, just like drafting paper" emphasizing its transience.

Table 7

Metaphors for the Being Necessary and Supportive Category

\begin{tabular}{|c|c|c|c|c|}
\hline No. & Metaphor & $\mathbf{f}$ & Resemblance aspect & Category \\
\hline 1 & Medicine & 23 & Being therapeutic & \\
\hline 2 & Hero & 11 & Rescuing from trouble & \\
\hline 3 & Water & 11 & Being indispensable & \\
\hline 4 & Crutch & 8 & Supporting walking & \\
\hline 5 & Food & 7 & Being indispensable & \\
\hline 6 & Vitamin & 6 & Fixing deficiencies & \\
\hline 7 & Band-aid & 5 & Being protective & \\
\hline 8 & Mask & 5 & Being protective & \\
\hline 9 & Respirator & 5 & Supporting breathing & \\
\hline 10 & Spare tire & 3 & Being reinforcing & \\
\hline 11 & First-aid kit & 3 & Emergency aid & \\
\hline 12 & Doctor & 3 & Being therapeutic & \\
\hline 13 & Cane & 3 & Supporting walking & \\
\hline 14 & Lifeguard & 3 & Emergency aid & \\
\hline 15 & Safety belt & 3 & Being protective & \\
\hline 16 & Hospital & 2 & Being therapeutic & Metaphors for the \\
\hline 17 & Boat & 2 & Rescuing from trouble & Being Necessary \\
\hline 18 & Patch & 2 & Fixing deficiencies & and Supportive \\
\hline 19 & First-aid & 2 & Emergency aid & \\
\hline 20 & Breath & 2 & Being indispensable & \\
\hline 21 & Life raft & 2 & Rescuing from trouble & \\
\hline 22 & Winter coat & 2 & Being protective & \\
\hline 23 & Prosthetics & 2 & Supporting walking & \\
\hline 24 & Sap water & 2 & Giving life & \\
\hline 25 & Draft paper & 1 & Being a need fulfillment & \\
\hline 26 & Fire extinguisher & 1 & Emergency aid & \\
\hline 27 & Intensive care & 1 & Being therapeutic & \\
\hline 28 & Desert plant & 1 & Being hope & \\
\hline 29 & Antidote & 1 & Removing the negative situation & \\
\hline 30 & IV Bag & 1 & Being therapeutic & \\
\hline 31 & Compensation training & 1 & Completing incomplete learning & \\
\hline 32 & Antibiotics & 1 & Being therapeutic & \\
\hline 33 & Sunglasses & 1 & Being protective & \\
\hline
\end{tabular}

Another prospective teacher (24.M) emphasized its capability to offer hope when everything else seemed gone with the metaphor "desert plant" "...because 
Metaphoric Perceptions of Pre-Service Teacher on Distance Education During...

it is an effort to ensure that education continues to keep up despite all adversities". The word cloud for the being necessary and supportive category is presented in Figure 6.

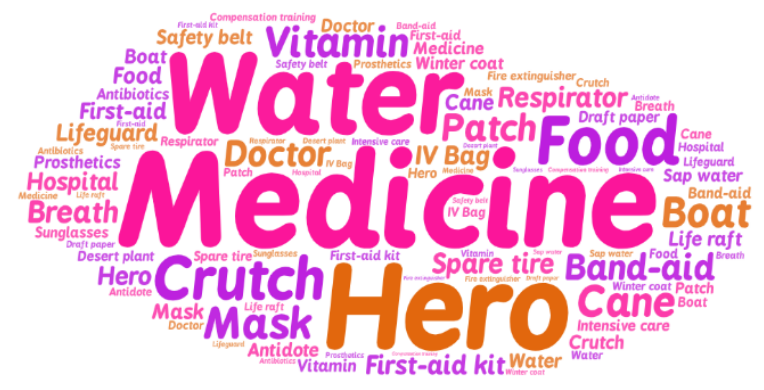

Figure 6. Word cloud for the being necessary and supportive category.

\section{Findings for negative metaphors}

This section presents the negative metaphors suggested for distance education during the pandemic by prospective teachers. metaphors

Findings for the complexity and uncertainty category and relevant

Another category that emerged for distance education during the pandemic was "Complexity and Uncertainty". This category and the metaphors it includes are presented in Table 8 . Table 8 indicates that there are 17 metaphors concerning the complexity and uncertainty category. These metaphors are, in order of frequency, Noise, Labyrinth, Darkness, Room in Disarray, Closed Box, Walking in the Dark, Looking for a Needle in a Haystack, Mirage, Sudden Snowfall, Surprise Egg, Baby, Big Rock at the Mouth of the Cave, Getting Lost, Being Blind, Truck with a Failed Brake, Fish out of the Water and Walking in the Desert. A prospective teacher (12.F) likened distance education during the pandemic to "noise", "...because there are many distractions since the lectures are not offered in a classroom". Another prospective teacher (393.F) who used the metaphor "labyrinth" said that it was "...because it's not that easy to find your path in distance education". A prospective teacher (305.M) likened it to "darkness" "...because you definitely cannot see ahead, anything can happen anytime". Another prospective teacher (103.M) likened distance education during the pandemic to a "room in disarray" "...because everything is in disarray and there are motivational problems". 


\section{Ayşe Ülkü KAN \& Erhan ÖZMEN}

\section{Table 8}

Metaphors for the Complexity and Uncertainty Category

\begin{tabular}{llllc}
\hline No. & Metaphor & f & Resemblance aspect & Category \\
\hline 1 & Noise & 3 & Consist of sound confusion & \\
2 & Labyrinth & 3 & Being unable to find the way & \\
3 & Darkness & 3 & Not being able to see the front & \\
4 & Room in disarray & 3 & Mixed items & \\
5 & Closed box & 3 & Not knowing inside & \\
6 & Walking in the dark & 2 & Not being able to see the front & Metaphors \\
7 & Looking for a needle in a haystack & 2 & Complexity & for the \\
8 & Mirage & 1 & Uncertainty & Complexity \\
9 & Sudden snowfall & 1 & Being unplanned & and \\
10 & Surprise egg & 1 & Not knowing what will come & Uncertainty \\
& & & out of it & Category \\
11 & Baby & 1 & Knowing nothing & \\
12 & Big rock at the mouth of the cave & 1 & Preventing seeing ahead & \\
13 & Getting lost & 1 & Being unable to find the way & \\
14 & Being blind & 1 & Not being able to see the front & \\
15 & Truck with a failed brake & 1 & Not knowing where to go & \\
16 & Fish out of the water & 1 & Knowing nothing & \\
17 & Walking in the desert & 1 & Not being able to see the front & \\
\hline
\end{tabular}

Another prospective teacher (65.F) used the metaphor "looking for a needle in a haystack" to emphasize the complexities of distance education during the pandemic "...because it is very difficult to track homework assignments for lessons, live classes, to find your way". Another prospective teacher (114.F) used the metaphor "mirage" "...because you can't be certain of what you will see when". A prospective teacher (165.F) likened distance education during the pandemic to a "sudden snowfall", emphasizing its unplanned nature, "...because at first it looks pretty and falls without any problems, but you can't know how it will end, everything is unplanned and sudden". Another prospective teacher (348.F) likened distance education during the pandemic to a "baby" "...because just like a newborn, it is a system without experience, which learns everything from the start". One prospective teacher (360.M) used the metaphor "truck with failed brakes", "...because it is filled with assignments with uncertain endings". The word cloud for the complexity and uncertainty category is presented in Figure 7. 
Metaphoric Perceptions of Pre-Service Teacher on Distance Education During...

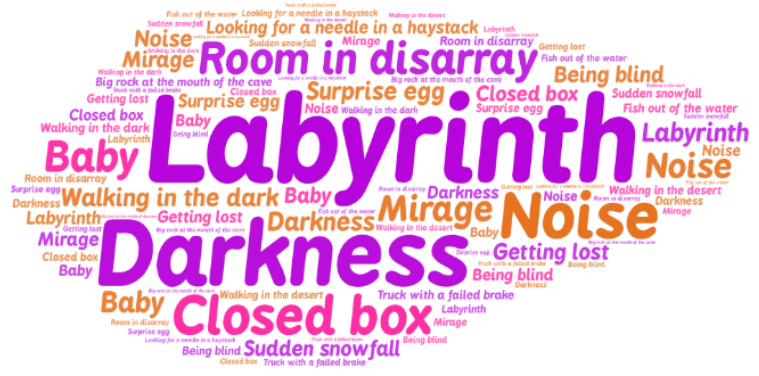

Figure 7. Word cloud for the complexity and uncertainty category.

\section{Findings for the inadequacy and inefficiency category and relevant metaphors}

Another category that emerged for distance education during the pandemic was "Inadequacy and Inefficiency". This category and the metaphors it includes are presented in Table 9.

Table 9 indicates that there are 48 metaphors concerning the inadequacy and inefficiency category. These metaphors are, in order of frequency, rowing against the current, fruitless tree, painkiller, imitation jewelry, free class, open education, car without gas, saltless food, consolation, bad friend, stepmother, sugarless tea, orphan, plastic glass, blown tire, half-full glass, ineffective medicine, eating but not growing, unpaid leave, watering stone and expecting flowers, badly written book, out of ink pen, infertile land, honeyless bees, car with blown tire, average student, waiting in line, shallow pool, weed, virtual life, bad sleep cycle, inorganic fruit, hot water, sapling, container-city, substitute product, tent, aquarium, running mill, gun without ammunition, lottery ticket with the smallest prize, youth, hay, medical student, unanswered love. The most common metaphor in this category was "rowing against the current". Five prospective teachers likened distance education during the pandemic to rowing against the current. One of these (72.F) said it was "...because I didn't see any of my efforts pay off". Another (314.F) said it was like a "fruitless tree" "...because a tree won't give you fruits if you can't touch it, can't water it with your own hands". A prospective teacher (75.F) likened distance education during the pandemic to a "painkiller" "...because it reduces the pain but doesn't cure it". Another prospective teacher (93.F) emphasized inefficacy and likened distance education during the pandemic to a "free class", "...because it is inefficient and is a waste of time on computer". 
Table 9

Metaphors for the Inadequacy and Inefficiency Category

\begin{tabular}{|c|c|c|c|c|}
\hline No. & Metaphor & $\mathbf{f}$ & Resemblance aspect & Category \\
\hline 1 & Rowing against the current & 5 & Not getting result & \\
\hline 2 & Fruitless Tree & 4 & Unable to give product & \\
\hline 3 & Painkiller & 4 & Lack & \\
\hline 4 & Imitation jewelry & 3 & Lack & \\
\hline 5 & Free class & 3 & Uselessness & \\
\hline 6 & Open education & 3 & Lack & \\
\hline 7 & Car without gas & 3 & Dysfunction & \\
\hline 8 & Saltless food & 3 & Lack of Taste & \\
\hline 9 & Consolation & 2 & Lack & \\
\hline 10 & Bad friend & 2 & Uselessness & \\
\hline 11 & Stepmother & 2 & $\begin{array}{l}\text { Make you feel the lack of the own } \\
\text { mother }\end{array}$ & \\
\hline 12 & Sugarless Tea & 2 & To be tasteless and incomplete & \\
\hline 13 & Orphan & 2 & Lack & \\
\hline 14 & Plastic glass & 2 & Lack & \\
\hline 15 & Blown tire & 2 & Dysfunction & \\
\hline 16 & Half-full glass & 2 & Lack & \\
\hline 17 & Ineffective medicine & 1 & Not getting result & \\
\hline 18 & Eating but not growing & 1 & Unable to give product & \\
\hline 19 & Unpaid leave & 1 & No return & Metaphors \\
\hline 20 & $\begin{array}{l}\text { Watering stone and expecting } \\
\text { flowers }\end{array}$ & 1 & Unable to give product & $\begin{array}{l}\text { for the } \\
\text { Inadequacy }\end{array}$ \\
\hline 21 & Badly written book & 1 & Uselessness & and \\
\hline 22 & Out of ink pen & 1 & Lack & Inefficiency \\
\hline 23 & Infertile land & 1 & Unable to give product & Category \\
\hline 24 & Honeyless bee & 1 & Unable to give product & \\
\hline 25 & Car with blown tire & 1 & Lack & \\
\hline 26 & Average student & 1 & Lack & \\
\hline 27 & Waiting in Line & 1 & Not getting result & \\
\hline 28 & Shallow pool & 1 & Lack & \\
\hline 29 & Weed & 1 & To be tasteless & \\
\hline 30 & Virtual life & 1 & Not being able to afford real life & \\
\hline 31 & Bad sleep cycle & 1 & Uselessness & \\
\hline 32 & Inorganic fruit & 1 & Lack of nutritional value & \\
\hline 33 & Hot water & 1 & Inability to quench thirst & \\
\hline 34 & Sapling & 1 & Need to improve & \\
\hline 35 & Container-city & 1 & Lack of accommodation facilities & \\
\hline 36 & Substitute product & 1 & $\begin{array}{l}\text { Doesn't replace the original } \\
\text { product }\end{array}$ & \\
\hline 37 & Tent & 1 & Lack of accommodation facilities & \\
\hline 38 & Aquarium & 1 & Not being substitute for the ocean & \\
\hline 39 & Running mill & 1 & Unable to move forward & \\
\hline 40 & Gun without ammunition & 1 & Dysfunction & \\
\hline
\end{tabular}


Metaphoric Perceptions of Pre-Service Teacher on Distance Education During...

$\begin{array}{llll}41 & \text { Lottery ticket with the } & 1 & \text { Lack } \\ & \text { smallest prize } & 1 & \text { Being inexperienced } \\ 42 & \text { Youth } & 1 & \text { Being tasteless and useless } \\ 43 & \text { Hay } & 1 & \text { Incomplete information } \\ 44 & \text { Medical student } & 1 & \text { Lack } \\ 45 & \text { Unrequited love } & 1 & \text { Lack } \\ 46 & \text { Unblooming Flower } & 1 & \text { Not having enough information } \\ 47 & \text { Summary } & 1 & \text { Not being versatile } \\ 48 & \text { One lane road } & \end{array}$

Another metaphor in this category is "car without gas". A prospective teacher (395.F) used this metaphor "...because it is a practice that is visible but non-functional". Another prospective teacher (170.M) likened it to a "stepmother" "...because you are missing a part of you all the time". Another prospective teacher (94.F) who emphasized the feeling of deficiency used the metaphor "unpaid leave", "...because it looks like a vacation but it actually is not" highlighting its uselessness. Another prospective teacher (131.F) used the metaphor "pen out of ink" "...because we actually try to teach and learn, but the lack of concrete experience reduces the permanence of what we teach and learn. We try to write with a pen that is just a vision, that doesn't leave a mark". A prospective teacher (146.F) likened distance education during the pandemic to a "honeyless bee" "...because distance education only makes noise. There is no product" indicating that she doesn't see any benefit. A prospective teacher (297.M) used the metaphor "bad sleep cycle", "...because just like a bad sleep cycle prevents you from having a quality day, distance education with its problems prevents you from having a quality education". Another metaphor in this category is "hot water". A prospective teacher (323.F) used this metaphor "...because the water fulfils your needs but doesn't quench your thirst". Another prospective teacher (357.F) likened distance education during the pandemic to an "aquarium", "...because if the distance education system is the aquarium, then we, the students, are the fish. Although our education continues, nothing can completely replace normal education. A fish can swim in an aquarium, but it can't find the pleasure and efficiency of swimming in the sea or ocean". Another prospective teacher (364.F) likened it to a "running mill", "...because however much you run, you always remain in the same place", emphasizing inadequacy and inefficiency. A prospective teacher (394.M) used "youth" as a metaphor "...because it looks pretty but it's inexperienced". A prospective teacher (384.M) indicated that distance education during the pandemic is tasteless by using the metaphor "hay", "...because you can eat it but you don't taste anything". Another prospective teacher (368.F) used the metaphor "medical student", "...because it knows some stuff but you can't entrust him with your health". Another metaphor in this category is "single-lane road". The prospective teacher who used this 
metaphor (271.F) said that it was "...distance education in the pandemic is oneway and doesn't offer you any other option". The word cloud for the inadequacy and inefficiency category is presented in Figure 8.

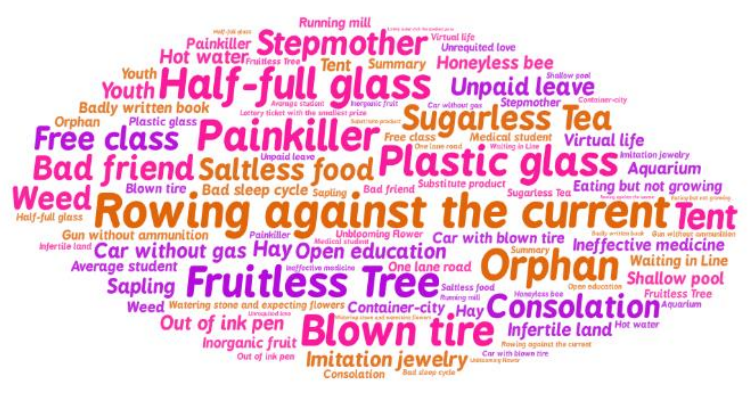

Figure 8. Word cloud for the inadequacy and inefficiency category.

\section{Findings for the non-interactivity category and relevant metaphors}

Another category that emerged for distance education during the pandemic was "non-interactivity". This category and the metaphors it includes are presented in Table 10.

Table 10 indicates that there are 13 metaphors concerning the individuality category. These metaphors are, in order of frequency, dream, wall, loneliness, robot, prison, television, apparition, stranger, mute person, soulless person, slavery, monologue. The most common metaphor in this category was "dream". A prospective teacher who used this metaphor (1.M) said it was "...because everything's in place, education continues, but you can only see it, not touch it" emphasizing the abstract nature of distance education. Another prospective teacher (35.F) used the metaphor "wall" "...because distance education stands like an obstacle before all our communication". Another prospective teacher thinks that distance education makes the student lonelier (62.M) "...because being physically distant from our teachers makes us psychologically lonelier". Another prospective teacher likened distance education during the pandemic to a "prison" (281.F) "...because the instructors constantly bombard us with assignments, like they are punishing us" emphasizing lack of interaction. A prospective teacher (Ö.A.101.F) used "television" as a metaphor for distance education during the pandemic, indicating its one-way nature "...because you can only watch and listen, you can't speak and state your problems". Another metaphor for noninteractivity was "stranger" and the prospective teacher who used it (109.M) said 
Metaphoric Perceptions of Pre-Service Teacher on Distance Education During...

that it was "...because it's something you know nothing about, you can't interact with".

\section{Table 10}

Metaphors for the Non-Interactivity Category

\begin{tabular}{llllc}
\hline No. & Metaphor & f & Resemblance aspect & Category \\
\hline 1 & Dream & 5 & Abstractness & \\
2 & Wall & 4 & Obstacle to interaction & \\
3 & Loneliness & 3 & Interaction disruption & \\
4 & Robot & 3 & Lack of interaction & \\
5 & Prison & 3 & Interaction disruption & Metaphors for the Non- \\
6 & Television & 3 & Unilateralism & Interactivity Category \\
7 & Apparition & 2 & Abstractness & \\
8 & Stranger & 2 & Lack of interaction & \\
9 & Mute person & 1 & Lack of interaction & \\
10 & Soulless person & 1 & Lack of interaction & \\
11 & Slavery & 1 & Interaction disruption & \\
12 & Monologue & 1 & Unilateralism & \\
13 & Armored vehicle & 1 & Obstacle to interaction & \\
\hline
\end{tabular}

Another prospective teacher (262.M) identified distance education during the pandemic with a "monolog" emphasizing its one-way nature just like the "television" metaphor "...because in the distance education during this time only the system speaks, you only listen". The word cloud for the non-interactivity category is presented in Figure 9.

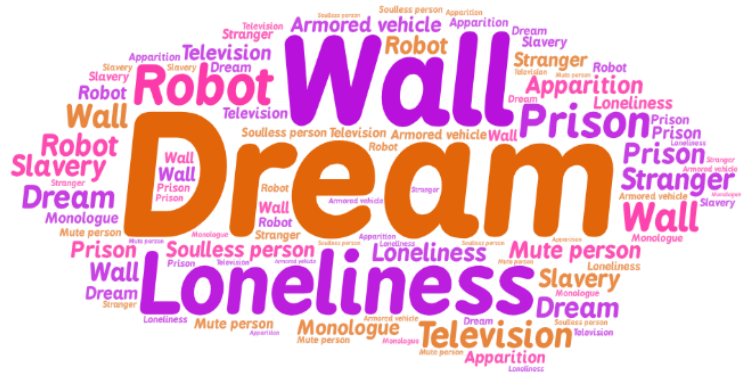

Figure 9. Word cloud for the non-interactivity category.

\section{Findings for the difficulty category and relevant metaphors}

Another category that emerged for distance education during the pandemic was "difficulty" This category and the metaphors it includes are presented in Table 11. 
Ayşe Ülkü KAN \& Erhan ÖZMEN

Table 11

Metaphors for the Difficulty Category

\begin{tabular}{lllll}
\hline No. & Metaphor & f & Resemblance aspect & Category \\
\hline 1 & Torture & 5 & To be boring and tough & \\
2 & Prison & 4 & Captivity & \\
3 & Ordeal & 3 & To be boring and tough & \\
4 & Illness & 3 & Difficult period & \\
5 & Cage & 3 & Captivity & Metaphors for \\
6 & Virus & 3 & Difficult period & the Difficulty \\
7 & Horse race & 2 & Tough competition & Category \\
8 & War & 2 & Being on the alert & \\
9 & Looking for water in the desert & 1 & Difficulty & \\
10 & Guardian & 1 & Supervisory pressure & \\
11 & Depression & 1 & Unhealthy thinking & \\
12 & Bumpy road & 1 & Difficult period & \\
\hline
\end{tabular}

Table 11 indicates that there are 12 metaphors concerning the difficulty category. These metaphors are, in order of frequency, torture, prison, ordeal, illness, cage, virus, horse race, war, looking for water in the desert, guardian, depression, bumpy road. The most common metaphor in this category was "torture". A prospective teacher using this metaphor (398.F) said it was "...because not being in the classroom at the same time with the instructor is boring and difficult", "Furthermore, assignments and lectures tired us even more in this period of bad psychology. Another prospective teacher (352.F) used the metaphor "prison" to indicate that they are not free, "...because it's an experience that I'm not used to, and it's a torturous process under difficult conditions". The "ordeal" metaphor in this category was used by a prospective teacher (280.F) "...because students both struggle with innumerable assignments, and shoulder their own personal responsibilities. Students couldn't study their lessons enough while trying to finish their assignments on time. In short, education during the pandemic was an ordeal for students", implying that homework assignments were excessive. Another prospective teacher (210.M) likened it to a "virus" "...because the assignments are making our lives as difficult as the virus does". Another prospective teacher (365.M) likened distance education during the pandemic to a "horse race" "...because instructors made us feel like we're in a horse race with their assignments". Another prospective teacher (47.M) who emphasized difficulties used the metaphor "war", "...because one must study and be careful all the time". One prospective teacher (141.F) used the metaphor "guardian", "...because it was a process in which I constantly had to catch up to many things in terms of control and discipline". The word cloud for the difficulty category is presented in Figure 10. 
Metaphoric Perceptions of Pre-Service Teacher on Distance Education During...

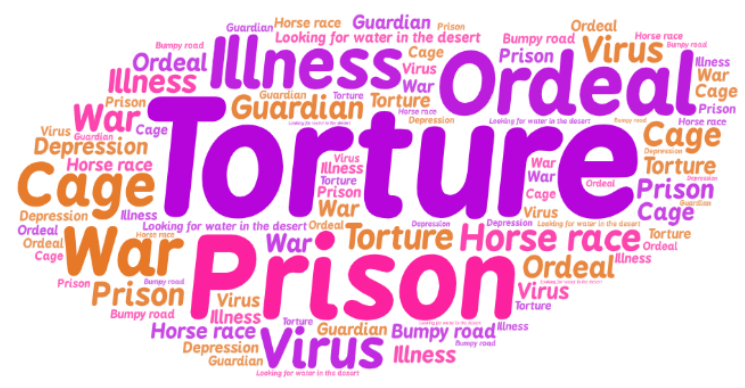

Figure 10. Word cloud for the difficulty category.

\section{DISCUSSION, RESULT AND RECOMMENDATIONS}

This section includes the conclusions reached based on the study findings, the discussions in which relevant studies are compared to the results, and the consequent recommendations for future studies. Metaphors conceptually label concepts, phenomena and events after filtering them through the individual's emotional world. Therefore, metaphors vary among individuals. This study aims to analyze metaphors for distance education used by prospective teachers who continued their education distancely during the pandemic and found that 402 prospective teachers used 178 different metaphors to define "distance education during the pandemic". The five most common metaphors used to define distance education during the pandemic were medicine, hero, water, food and vitamin. There were 88 metaphors under six positive categories, and 90 metaphors under four negative categories. The distribution of positive and negative metaphors were even. In a similar study on distance education, it was seen that metaphors were classified as positive and negative (Gömleksiz and Fidan, 2017). On current study, most of these metaphors (129 metaphors) were used only once. This indicates that metaphors differ based on individual experience. A similar situation was found in other studies (Cisek, 1999). Therefore, the diversity of metaphors was interpreted to be an indicator of the mental richnes of prospective teachers. 178 metaphors were classified in the 10 following categories: Individuality, Continuity, Diversity, Guidance, Affordability and Accessibility, Necessary and Supportive, Complexity and Uncertainty, Inadequacy and Inefficiency, Noninteractivity and Difficulty.

There are many studies that attempt to explain and define distance education (Çivril, Aruğaslan and Özkara, 2018; Yılmaz and Güven, 2015; Fidan, 2017; Tuncay and Özçınar, 2009) and distance education during the pandemic 
(Bozkurt, 2020; Bozdağ and Dinç, 2020; Abaslı and Caferova, 2020) through metaphors The difference of this study from previous studies is the diversity of participants and metaphors. This diversity aims to gain more in-depth knowledge about the matter.

The first category that emerged from the metaphors used by prospective teachers was "Individualism". Prospective teachers stated that distance education during the pandemic could be controlled by the individual's own efforts, and mostly used the metaphors reading a book, gear shift, swimming and control. Some distance education studies also similarly emphasize individual learning, individual speed and control (Marc, 2002; Klein and Ware, 2003; Amer, 2007; Algathani, 2011; Yılmaz and Güven, 2015; Çivril, Aruğaslan and Özkara, 2018).

In the continuity category, participants indicated that the knowledge is stored for long-term, and allows for lifelong learning through the metaphors refrigerator, powerbank and lifelong learning; this echoes the lifelong learning emphasis in Bozkurt's study (2020). Rainbow, google, book and soup were the most common metaphors in the diversity category. Prospective teachers indicated that distance education during the pandemic was rich in terms of diversity of information. In a similar study (Y1lmaz and Güven, 2015) explained distance education with the metaphors soup, rainbow and mosaic, suggesting a similarity in study results. Similarly, Tuncay and Özçınar (2009) used the "ocean" metaphor for distance education, emphasizing diversity. In the guidance category, technical coach, flashlight and compass metaphors were used by prospective teachers to indicate that distance education during the pandemic was a guide for them, and emphasized the "guidance" aspect, which is not frequently observed among metaphors for distance education.

In this study, Prospective teachers commonly used the metaphors friend, mother, magic lamp and Google in the affordability and accessibility category, suggesting that distance education during the pandemic facilitated education in terms of time and transportation, that everyone could access distance education. Studies that indicate that one of the most important aspects of distance education is facilitating education for students in terms of time and space support these results (Yılmaz and Güven, 2015; Bozkurt, 2020; Fidan; 2017; Demir, 2014; İşman, 2008). The most common metaphors used by students were medicine, hero, water, crutch and food and were included in the "being necessary and supportive" category. This indicates that prospective teachers consider distanceeducation necessary, and that distance education helped them during the pandemic. Furthermore, the being necessary and supportive category was the category with most metaphors (33). Prospective teachers likened distance 
Metaphoric Perceptions of Pre-Service Teacher on Distance Education During...

education during the pandemic to a medicine, consistent with other similar studies (Bozkurt, 2020; Y1lmaz and Güven, 2015; Çivril, Aruğaslan and Özkara, 2018 ) The most common metaphor in terms of repetitions was "medicine". While the being necessary and supportive category describes getting rid of a generally difficult situation, it also sometimes emphasizes indispensability and protectiveness. Mask, band-aid and safety belt were also used as metaphors for distance education during the pandemic with its protectiveness aspect. The second most common metaphor was "hero" (used 11 times). The results of Tuncay and Özçınar's (2009) study similarly likens distance education to computer heroes. This is consistent with our study.

The first category of negative metaphors used for distance education during the pandemic was "complexity and uncertainty". Noise, labyrinth, darkness, room in disarray, closed box were the common metaphors in the complex and uncertainty. Unplanned nature of the pandemic and the reflection of this lack of planning on distance education was a general justification for these metaphors. Some studies concluded that classes during the pandemic were not adequately planned and these support the findings of this study (Zan and Zan, 2009; Bozkurt, 2020). The category that included the most metaphors (48) was "inadequacy and inefficiency" distance education during the pandemic was considered useless and deficient. Students considered face-to-face comparisons when using these metaphors, and stated that distance education during the pandemic was deficient in many ways. Similarly, Fidan's study (2017) found that distance education was associated with metaphors indicating uselessness such as vain jobs, unnecessary classes and killing time. Similarly, Bozkurt (2020) found statements that indicate the inadequacy of distance education such as turned off light, mask, salt and chaos. Another metaphor category was "non-interactivity". Dream, wall, loneliness, robot and prison metaphors were metaphors that were commonly repeated. Prospective teachers defined distance education during the pandemic defective in terms of communication. Some sources investigated the disadvantages of distance education (Altun, 2020) and support the study results with an emphasis on social isolation. Some study results are similar to previous studies. This indicates that distance education during the pandemic should be improved in terms of interaction (Çivril, Aruğaslan and Özkara, 2018; Y1lmaz and Güven, 2015; Bozkurt, 2020; Abaslı and Caferova, 2020). Torture, prison, ordeal, illness, cage and virus were the most common metaphors used in the difficulty category. Prospective teachers mentioned a heavy load of assignments by instructors, and their inadequacy in terms of distance education, leading to a difficult process for them. 
Considering the study results, we can state that both positive and negative metaphors were used, contributing to the establishment of semantic categories associated with prospective teachers' experiences with distance education during the pandemic. In this regard, the establishment of positive categories is a happy and desired consequence. However, the negative metaphors and conceptual categories that emerged also indicate that prospective teachers experience difficulties in the process, and that these experiences affect their semantic perceptions. Considering all this and the study results, we developed the following recommendations.

- Considering the current and potential future situations such as pandemics, etc., an emergency remote teaching plan and contents should be developed for education organizations. This may allow forming better perceptions about the process.

- Carrying out distance education activities that support conventional education even before extraordinary situations (pandemics, etc.) occur may ensure better preparedness for potential emergencies.

-Trainings that improve techno-pedagogic capabilities of instructors in terms of distance education should be provided and activities that increase their distance education experience should be conducted.

- Mentimeter, kahoot, quizizz, thinklink, ed.ted and similar web 2.0 applications should be used to improve interaction in distance education and instructors should be trained in these subjects.

-Budgets should be planned to establish the necessary system infrastructure for potential emergency mass remote teaching, and to improve the technical access opportunities of students.

- It is thought that it may be important to systematically handle measurement and evaluation activities in distance education in a process and result-oriented manner. Therefore, instead of giving out difficult and intense assignments to students, giving them critical responsibilities may ensure that they are more engaged in the learning process.

\section{REFERENCES}

Abasl1, K. \& Caferova, S. (2020). Distance education in the pandemic period: A metaphor analysis. Azerbaijan Journal of Educational Studies, 690(1), 1026. 
Metaphoric Perceptions of Pre-Service Teacher on Distance Education During...

Altun, E. (2020). Eğitmenlerin Uzaktan Ĕgitime Yönelik Pedagojik Yeterliliklerinin Uzaktan Eğitim Ders Videolari Araciliğiyla İncelenmesi. Yayımlanmamış yüksek lisans tezi, Ondokuz Mayıs üniversitesi Eğitim Bilimleri Enstitüsü.

Algahtani, A.F. (2011). Evaluating the Effectiveness of the E-learning Experience in Some Universities in Saudi Arabia from Male Students' Perceptions. Yayımlanmamış yüksek lisans tezi, Durham University.

Amer, T. (2007). E-learning and Education. Dar Alshehab publication.

Arat, T, Bakan, Ö. (2014). Uzaktan eğitim ve uygulamaları. Selçuk Üniversitesi Sosyal Bilimler Meslek Yüksekokulu Dergisi, 14 (1-2), 363-374.

Bozdağ, B. \& Dinç, F. (2020). The perceptions of physical education teacher candidates towards the concept of distance education in the covid-19 process: a metaphor study. International Journal of Eurasian Education and Culture, 5(11), 1954-1980.

Bozkurt, A. (2020). Koronavirüs (Covid-19) pandemisi sirasinda ilköğretim öğrencilerinin uzaktan eğitime yönelik imge ve algilari: Bir metafor analizi. Uşak Üniversitesi Eğitim Araştırmaları Dergisi, 6(2), 1-23.

Cebeci, O. (2013). Metafor ve Şiir Dilinin Yapısal Özellikleri. İthaki Yayınları.

Cisek, P. (1999). Beyond the computer metaphor: Behaviour as interaction. Journal of Consciousness Studies, 6(11-12), 125-142.

Çivril, H., Aruğaslan, E. \& Özkara, B. Ö. (2018). Uzaktan eğitim öğrencilerinin uzaktan eğitime yönelik algilari: Bir metafor analizi. Eğitim Teknolojisi Kuram ve Uygulama, 8(1), 39-59.

Demir, E. (2014). Uzaktan eğitime genel bir bakış. Dumlupinar University Journal of Social Science, (39).

Fidan, M. (2017). Karma öğrenme öğrencilerinin uzaktan eğitim kavramına yönelik metaforik alg1lar1. International Online Journal of Educational Sciences, 9(1), 276-291.

Gökçe, O. (2006). İçerik Analizi: Kuramsal ve Pratik Bilgiler. Siyasal Kitabevi.

Gömleksiz, M. N. \& Fidan, E. K. (2017). Meslek yüksekokulu öğrencilerinin uzaktan eğitime ilişkin metaforik algıları. VII. Uluslararası Eğitimde Araştırmalar Kongresi Bildirileri (ULEAD). Çanakkale 18 Mart Üniversitesi. 27-29 Nisan, 100-105. 
Hodges, C., Moore, S., Lockee, B., Trust, T. \& Bond, A. (2020). Acil Uzaktan Öğretim ile Çevrimiçi Öğrenme Arasındaki Fark. https://er.educause.edu/ articles/2020/3/the-difference-between-emergency-distance teaching-andonlinelearning?fbclid=IwAR3Y4YcefHyQCxRZBYoS9UbPjESkUIIC4 WVc_BYm3nu0pHs7D5LBys4HuFw, Erişim tarihi: 20.12.2020

İşman, A. (2008). Uzaktan Ĕgitim. Pegem Akademi.

Kaban, A. (2013). Uzaktan Eğitim Kalite Standartlarinin Belirlenmesi ve Atatürk Üniversitesi Uzaktan Eğitim Sisteminin Incelenmesi. Yayımlanmamış doktora tezi, Gazi Üniversitesi Eğitim Bilimleri Enstitüsü.

Karataş, Z. (2015). Sosyal bilimlerde nitel araştirma yöntemleri. Manevi Temelli Sosyal Hizmet Araştirmalari Dergisi, 1(1), 62-80.

Kılıç, F. \& Arakan, K. (2010). Birinci sinif velilerinin veli eğitimine ve çocuklarinin okula başlamalarina ilişkin algilarinin metaforlar (mecazlar) yardimiyla analizi. 9. Ulusal Sinıf Öğretmenliği Eğitimi Sempozyumu Bildirileri. Firat Üniversitesi, 20-22 Mayıs, 908-910.

Klein, D. \& Ware, M. (2003). E-learning: new opportunities in continuing professional development. Learned Publishing, 16 (1) 34-46.

Lakoff, G. \& Johnson, M. (2005). Metaphor We Live By. London.

Liu, Y., Gayle, A. A., Wilder-Smith, A. \& Rocklöv, J. (2020). The reproductive number of COVID-19 is higher compared to SARS coronavirus. Journal of Travel Medicine, 27(2), 1-4.

Marc, J. R. (2002). Book review: e-learning strategies for delivering knowledge in the digital age. Internet and Higher Education, 5, 185-188.

Miles, M, B. \& Huberman, A. M. (1994). Qualitative Data Analysis: An Expanded Sourcebook (2nded). Thousand Oaks. Sage.

Morgan, D. L. (1998). Practical strategies for combining qualitative and quantitative methods: Applications to health research. Qualitative Health Research, 8(3), 362-376.

Ocak, G. \& Gündüz, M. (2006). Öğretmenlik mesleğine giriş dersini almadan önce ve aldiktan sonra öğretmenlik mesleği hakkindaki metaforlarinin karşilaştirilmasi. Afyon Kocatepe Üniversitesi Sosyal Bilimler Enstitüsü Dergisi, 8(2), 293-310.

Öz, S., Celayir, D. \& Onursal, F. S. (2020). Pandemi Sonrasi Yeni Dünya Düzeninde Teknoloji Yönetimi ve Insani Dijitalizasyon. Hiperyayın. 
Metaphoric Perceptions of Pre-Service Teacher on Distance Education During...

Özdemir, M. (2010). Nitel veri analizi: Sosyal bilimlerde yöntembilim sorunsali üzerine bir çalişma. Eskişehir Osmangazi Üniversitesi Sosyal Bilimler Dergisi, 11(1), 323- 343.

Patton, M. Q. (2002). Qualitative Research \& Evaluation Methods. Sage.

Saban, A., Koçbeker, B. N. \& Saban, A. (2006). An investigation of the concept of teacher among prospective teachers through metaphor analysis. Educational Sciences: Theory \& Practice, 6(2), 509-522.

Sağlık Bakanlığ1 (2020, Mart). Genel koronavirüs tablosu vaka sayıları. https://covid19.saglik.gov.tr/TR-66935/genel-koronavirus-tablosu.html, Erişim tarihi: 012.01.2021

Shisley, S. (2020). Emergency Distance Learning Compared to Online Learning. https://learningsolutionsmag.com/articles/emergency-distance-learningcompared-to-online-learning, Erişim tarihi: 01.01.2021

Telli, S. G. \& Altun, D. (2020). Coronavirüs ve çevrimiçi (online) eğitimin önlenemeyen yükselişi. Üniversite Araştırmaları Dergisi, 3(1), 25-34.

Traxler, J. (2018). Distance learning predictions and possibilities. Education Sciences, 8(35), 1-13

Tuncay, N. \& Özçinar, Z. (2009). Distance education students" "metaphors". Procedia-Social and Behavioral Sciences, 1(1), 2883-2888.

Ulus, İ. Ç. (2020). Acil durum uzaktan eğitim ve uzaktan eğitim. https://epale.ec. europa.eu/en/blog/emergency-distance-education-vs-distance-education, Erişim tarihi: 01.01.2021

Uşun, S. (2006). Uzaktan Eğitim. Nobel Yayın Dağıtım.

Yalçın, M., \& Erginer, A. (2012). Metaphoric perception of principals in primary schools. Journal of Teacher Education and Educators, 1(2), 229-256.

Yıldırım, A. \& Şimşek, H. (2016). Sosyal Bilimlerde Araştırma Yöntemleri. Seçkin Yayıncılık.

Yılmaz, G. K. \& Güven, B. (2015). Öğretmen adaylarının uzaktan eğitime yönelik algılarının metaforlar yoluyla belirlenmesi. Turkish Journal of Computer and Mathematics Education, 6(2), 299-322.

YÖK (2020, Mart). Basın Açıklaması. YÖK Başkanı Prof. Dr. Yekta SARAÇ. https://www.yok.gov.tr/Sayfalar/Haberler/2020/universitelerde-uygulana cak-uzaktan-egitime-iliskin-aciklama.aspx, Erişim tarihi: 13.01.2021 
Zan, N., \& Zan, B. U. (2020). Koronavirüsile acil durumda eğitim: Türkiye'nin farkli bölgelerinden uzaktan eğitim sistemine dahil olan edebiyat fakültesi öğrencilerine genel bakiş. Electronic Turkish Studies, 15(4).

Zhong, R. (2020). The coronavirus exposes education's digital divide. The New York Times. https://www.nytimes.com/2020/03/17/technology/chinaschoolscoronavirus.html, Erişim tarihi: 02.01.2021

\section{EXTENDED ABSTRACT}

Purpose: The purpose of this study is to reveal the perceptions of pre-service teachers towards distance education applied during the covid-19 pandemic through metaphors. For this purpose, answers to the following questions were sought in the study: (1) What are the metaphors pre-service teachers created regarding distance education during the pandemic?; (2) In which conceptual categories can the metaphors created by pre-service teachers be collected?

Method: In this study, phenomenology, which is a qualitative study method, was used. Phenomenology is a qualitative study method that investigates in detail the facts that we encounter but don't have in-depth information about, or didn't think about (Yıldırım and Şimşek, 2016). Phenomenology studies investigate groups in terms of their feelings about their experiences, the concepts they create in their minds and their opinions. It examines the state of consciousness that consequently emerges (Patton, 2002). In studies in accordance with the phenomenological pattern, data analysis is carried out through content analysis that can reveal meanings. The aim is to reach themes that can express the phenomenon (Yildirım and Şimşek, 2016). In this study, perceptions of prospective teachers concerning the distance education practice during the pandemic were determined through metaphors and interpreted. "Convenience sampling" was used as sampling method in this study. This study uses an interview form developed by the authors for data collection. This form asks the participant to fill in the blanks in the statement "Distance education is like Because..................". This study uses content analysis, a data analysis method frequently used in social sciences. Content analysis is a method that differentiates, compares, systematizes the data through an in-depth process, and to interpret the results in a comprehensible manner (Yıldırım and Şimşek, 2016).

Findings: The metaphors revealed were classified under 10 categories (six positive, four negative). Positive categories were Individuality, Continuity, Diversity, Guidance, Affordability and Accessibility, Necessary and Supportive; negative categories were Complexity and Uncertainty, Inadequacy and 
Metaphoric Perceptions of Pre-Service Teacher on Distance Education During...

Inefficiency, Non-interactivity and Difficulty. There are 13 metaphors concerning the individuality category. These metaphors are, in order of frequency, reading a book, gear shift, swimming, control, canoe, bicycle, rope jumping, tree climbing, chick hatching from an egg, flower care, study room, ploughing a field and pandemic. The most frequent metaphor used by prospective teachers in this category was "reading a book". There are three metaphors concerning the continuity category. These metaphors are, in order of frequency, refrigerator, powerbank and lifelong learning. In the continuity category, the most common metaphors used by prospective teachers were refrigerator and powerbank. There are 15 metaphors concerning the diversity category. These metaphors were, in order of frequency, rainbow, google, book, soup, sea, ashura, exhibition, YouTube, capsule, world, internet, marketplace, social media, and Istanbul. The most frequent metaphor used by prospective teachers in the diversity category was "rainbow". There are six metaphors concerning the guidance category. These metaphors are, in order of frequency, technical coach, flashlight, compass, north star, guide and mirror. there are 18 metaphors concerning the diversity category. These metaphors are, in order of frequency, friend, mother, magic lamp, google, street lamp, jet, airplane, bridge, neighbor, school at home, teaser trailer, social media, star in the sky, time travel, magic carpet, lottery, and discount. 33 metaphors concerning the diversity category. These metaphors are, in order of frequency, medicine, hero, water, crutch, food, vitamin, band-aid, mask, respirator, spare tire, first-aid kit, doctor, cane, lifeguard, safety belt, hospital, boat, patch, breath, first-aid, life raft, winter coat, prosthetics, sap water, draft paper, fire extinguisher, intensive care, desert plant, antidote, IV bag, compensation training, antibiotics, and sunglasses. there are 17 metaphors concerning the complexity and uncertainty category. These metaphors are, in order of frequency, Noise, Labyrinth, Darkness, Room in Disarray, Closed Box, Walking in the Dark, Looking for a Needle in a Haystack, Mirage, ,Sudden Snowfall, Surprise Egg, Baby, Big Rock at the Mouth of the Cave, Getting Lost, Being Blind, Truck with a Failed Brake, Fish out of the Water and Walking in the Desert. There are 48 metaphors concerning the inadequacy and inefficiency category. These metaphors are, in order of frequency, rowing against the current, fruitless tree, painkiller, imitation jewelry, free class, open education, car without gas, saltless food, consolation, bad friend, stepmother, sugarless tea, orphan, plastic glass, blown tire, half-full glass, ineffective medicine, eating but not growing, unpaid leave, watering stone and expecting flowers, badly written book, out of ink pen, infertile land, honeyless bees, car with blown tire, average student, waiting in line, shallow pool, weed, virtual life, bad sleep cycle, inorganic fruit, hot water, sapling, container-city, substitute product, tent, aquarium, running mill, gun without ammunition, lottery ticket with the smallest prize, youth, hay, 
medical student, unanswered love. There are 13 metaphors concerning the individuality category. These metaphors are, in order of frequency, dream, wall, loneliness, robot, prison, television, apparition, stranger, mute person, soulless person, slavery, monologue. The most common metaphor in this category was "dream" there are 12 metaphors concerning the difficulty category. These metaphors are, in order of frequency, torture, prison, ordeal, illness, cage, virus, horse race, war, looking for water in the desert, guardian, depression, bumpy road. The most common metaphor in this category was "torture".

Result and Argument: Metaphors conceptually label concepts, phenomena and events after filtering them through the individual's emotional world. Therefore, metaphors vary among individuals. This study aims to analyze metaphors for distance education used by prospective teachers who continued their education distancely during the pandemic and found that 402 prospective teachers used 178 different metaphors to define "distance education during the pandemic". The five most common metaphors used to define distance education during the pandemic were medicine, hero, water, food and vitamin. There were 88 metaphors under six positive categories, and 90 metaphors under four negative categories. The distribution of positive and negative metaphors were even. Most of these metaphors (129 metaphors) were used only once. This indicates that metaphors differ based on individual experience. A similar situation was found in other studies (Cisek, 1999). Therefore, the diversity of metaphors was interpreted to be an indicator of the mental richnes of prospective teachers. 178 metaphors were classified in the 10 following categories: Individuality, Continuity, Diversity, Guidance, Affordability and Accessibility, Necessary and Supportive, Complexity and Uncertainty, Inadequacy and Inefficiency, Non-interactivity and Difficulty. There are many studies that attempt to explain and define distance education (Çivril, Ağusaslan and Özkara, 2018; Yılmaz and Güven, 2015; Fidan, 2017; Tuncay and Özçınar, 2009) and distance education during the pandemic (Bozkurt, 2020; Bozdağ and Dinç, 2020; Abaslı and Caferova, 2020) through metaphors. 